\title{
IT BALANCED SCORECARD AS IT GOVERNANCE FRAMEWORK
}

\author{
KoZINA, M.
}

Abstract: Information Technology (IT) is one of the leading 'high' technologies and has an increasing role in the area of modern business. IT investments most often result in insufficient returns, which points to the need for development of IT management. The main question today isn't whether to use IT or not, but rather to which extent and how. An important aspect of IT management has been developing lately, called IT Governance, or, in other words, IT business value management. This paper contains an analysis of IT Balanced Scorecard (IT BSC) as an important instrument in support of IT Governance processes. The mission of IT BSC is to develop strategic goals and indicators for the establishment of adequate organization of IT processes which would connect business and IT strategies. To that end, the IT BSC maturity model has been formed, guiding IT management to scorecard process improvements, especially those of IT Strategic BSC. Further research should define this instrument in more detail, and especially the relationship between the outcome measures and performance drivers within IT BSC as a support of the Business BSC.

Key words: Business/IT Alignment, IT Governance, IT BSC, Balanced Scorecard Cascade, IT BSC Maturity Model
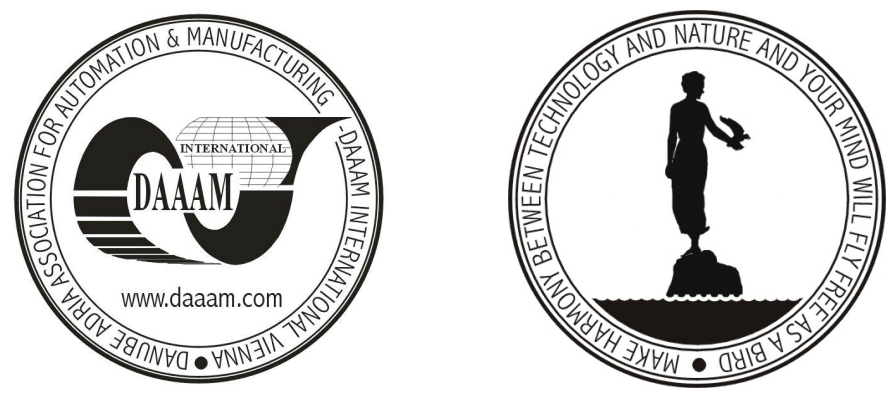

Authors' data: Ph.D Information Sciences Kozina M.[elita], Faculty of Organization and Informatics, Croatia, melita.kozina@foi.hr

This Publication has to be referred as: Kozina, M. (2006). IT Balanced Scorecard as IT Governance Framework, Chapter 28 in DAAAM International Scientific Book 2006, B. Katalinic (Ed.), Published by DAAAM International, ISBN 3-901509-47-X, ISSN 1726-9687, Vienna, Austria

DOI: $10.2507 /$ daaam.scibook.2006.28 